\title{
KORELASI INDEKS MASA TUBUH (BMI) DAN INDEKS KARIES (def-t) PADA ANAK USIA SEKOLAH DASAR DI KABUPATEN BANDUNG
}

\author{
Emma Rachmawati*, Risti Primarti Saptarini**, Yuliawati Zenab"***, Mirna Febriani***** \\ *Departemen Biologi Oral, Fakultas Kedokteran Gigi Universitas Padjadjaran, Bandung \\ **Departemen Kedokteran Gigi Anak, Fakultas Kedokteran Gigi, Universitas Padjadjaran, Bandung \\ ***Departemen Ortodonti, Fakultas Kedokteran Gigi, Universitas Padjadjaran, Bandung \\ ****Departemen Ilmu Material dan Teknologi Kedokteran Gigi, Fakultas Kedokteran Gigi, Universitas Prof. Dr. \\ Moestopo (Beragama), Jakarta \\ Korespondensi: emma.rachmawati@fkg.unpad.ac.id
}

\begin{abstract}
ABSTRAK
Latar belakang: kondisi kesehatan umum anak dapat diketahui melalui pengukuran indeks masa tubuh atau body mass indeks (BMI). BMI dapat digunakan sebagai sarana penilaian malnutrisi dengan membandingkan berat badan dan tinggi badan anak menurut usia. BMI memiliki hubungan dengan kondisi kesehatan mulut anak yang ditandai dengan indeks OHI-S yang secara signifikan memiliki hubungan erat dengan indeks def-t. Tujuan: tujuan penelitian ini adalah untuk mengetahui korelasi antara BMI dan def-t anak usia sekolah dasar di Kabupaten Bandung. Metode: penelitian ini merupakan penelitian deskriptif dengan menggunakan metode cross sectional. Sampel penelitian adalah 228 siswa sekolah dasar berusia 5-9 tahun dengan ketentuan tidak memiliki sejarah penyakit sistemik. BMI ditentukan dengan mengukur berat badan dan tinggi badan anak disesuaikan dengan usia, sedangkan indeks karies ditentukan

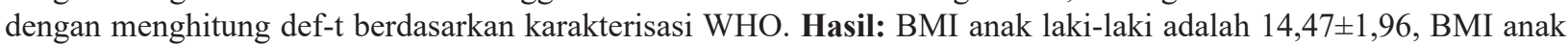
perempuan adalah $14,62 \pm 1,74$ sedangkan rata-rata def-t adalah 8,84 . Penghitungan korelasi dengan menggunakan Spearman rank didapat nilai $\mathrm{p}$ korelasi adalah $0,350(\mathrm{p}>0,05)$, hal ini menunjukkan tidak terdapat hubungan yang signifikan antara def-t dengan BMI. Penghitungan korelasi Spearman rank untuk BMI dan def-t berdasarkan gender memperlihatkan nilai $\mathrm{p}$ untuk anak laki-laki adalah $0,385(\mathrm{p}>0,05)$ dan anak perempuan adalah $0,738(\mathrm{p}>0,05)$, hal ini menunjukkan tidak terdapat korelasi yang signifikan antara BMI dan def-t baik pada anak laki-laki maupun perempuan. Kesimpulan: hasil penelitian menunjukkan tidak terdapat korelasi antara BMI dan def-t baik pada anak laki-laki maupun pada anak perempuan usia sekolah dasar di Kabupaten Bandung
\end{abstract}

Kata kunci: Indeks masa tubuh (BMI), indeks karies (def-t), anak usia sekolah dasar.

\begin{abstract}
Background: the general health status of the child is characterized by determining the body mass index or BMI through measurements of weight and height which is used as an assessment of malnutrition by comparing the child's weight and height for age. BMI has a relationship with the oral health status of children indicated by the OHI-S index which is significantly correlated with the def-t index. Purpose: the purpose of this study was to determine the correlation between BMI and def-t of elementary school age children in Bandung District. Method: this research was a descriptive study using cross sectional method. The research sample was 228 elementary school students of aged 5-9 years with the condition that they did not have any history of systemic diseases. BMI was determined by measuring the child's weight and height according to age, while the def-t was determined by examining the primary teeth based on WHO characterization. Result: males' BMI is $14.47 \pm 1.96$, females' BMI is $14.62 \pm 1.74$ meanwhile the mean of def- $t$ is 8.84. Based on the results calculation using the Spearman rank, it was found that the p-value of the correlation is 0.350 ( $p>0.05$ ), indicating that there is no significant relationship between def-t and BMI. Meanwhile the calculation of the Spearman rank for correlation between BMI and def-t based on gender shows that the p-value for male is 0.385 $(p>0.05)$ and for female is $0.738(p>0.05)$, this shows that there is no significant correlation between BMI and def- $t$ in both males and females. Conclusion: the result shows that there is no correlation between BMI and def-t both among male and female children of elementary age in Bandung District
\end{abstract}

Keywords: Body mass index (BMI), caries indeks (def-t), children of elementary age. 


\section{PENDAHULUAN}

$W$ Forld Health Organization (WHO) telah menyatakan bahwa kejadian karies pada anak mencapai $60-90 \%$, dan nilai ini terlihat terus meningkat seiring bertambahnya usia. Di Indonesia $60 \%$ anak usia 3 tahun telah menderita karies gigi dan persentasenya terus meningkat yaitu $85 \%$ untuk anak usia 4 tahun dan $86,4 \%$ untuk anak usia 5 tahun. Dengan demikian, dapat disimpulkan bahwa karies gigi merupakan penyakit rongga mulut yang umum terjadi pada anak-anak dan bila tidak ditangani akan terjadi komplikasi penyakit gigi mulut yang parah seperti abses akut atau kronis. ${ }^{1}$ Faktor utama penyebab karies adalah kebersihan mulut, bakteri, saliva dan pola makan. Di samping itu, terdapat faktor lain yang tidak kalah pentingnya yaitu umur, jenis kelamin, status sosial geografis dan perilaku. ${ }^{2,3}$ Faktor perilaku dan umur merupakan faktor yang sangat kuat pengaruhnya terhadap timbulnya karies gigi. Kedua faktor ini berkaitan erat dengan kesadaran akan pentingnya menjaga kebersihan mulut dan sangat berpengaruh terhadap inisiasi dan perkembangan karies gigi. ${ }^{4}$ Kemampuan anak di dalam memelihara kebersihan gigi akan berdampak pada mikroflora rongga mulut terutama Streptococcus mutans dan pertumbuhan mikroorganisme Gram (-) yang berperan utama dalam proses karies gigi. ${ }^{5} \mathrm{Kelompok}$ anak risiko tinggi terhadap karies adalah anak berusia $11-14$ tahun yang disebabkan karena adanya perubahan pola makan seperti kebiasaan mengonsumsi kudapan di sela waktu makan, tetapi karies gigi sebenarnya merupakan kondisi yang dapat dimulai sejak usia dini. ${ }^{6}$

Komplikasi karies gigi yang tidak dirawat di kalangan anak-anak seperti infeksi dan inflamasi kronis akan menyebabkan gangguan kesehatan secara umum. Kondisi kesehatan umum anak umumnya ditetapkan dengan menentukan indeks masa tubuh atau BMI melalui pengukuran berat dan tinggi badan. ${ }^{2,7}$ WHO menentukan penilaian malnutrisi dengan membandingkan berat badan dan tinggi badan disesuaikan dengan usia. Beberapa literatur telah mendokumentasikan adanya hubungan antara BMI dengan kondisi kesehatan mulut anak-anak ditandai dengan indeks OHI-S yang secara signifikan memiliki hubungan erat dengan indeks def-t. ${ }^{8,9}$ Hubungan BMI dengan $\mathrm{OHI}-\mathrm{S}$ sebagai penyebab karies gigi merupakan hubungan yang cukup kompleks karena banyak faktor yang mempengaruhinya seperti umur, kualitas nutrisi, perilaku makan, dan perilaku memelihara kebersihan mulut. ${ }^{10}$ Berdasarkan Data Nasional (Riskesdas tahun 2018) prevalensi gizi buruk pada anak Indonesia tergolong tinggi yaitu $30,81 \%$, dan menurut UNICEF (1998) hal ini disebabkan karena 2 faktor penting yaitu langsung dan tidak langsung yang didukung faktor tingkat konsumsi pangan. ${ }^{11}$

Berdasarkan penelitian terdahulu mengenai status kesehatan gigi anak-anak usia sekolah dasar di kota Bandung memperlihatkan hasil indeks def-t yang cukup tinggi yaitu 5,09 untuk anak laki-laki dan 3,70 untuk anak perempuan. Kondisi ini kemungkinan diakibatkan oleh kesadaran tentang kesehatan gigi mulut di kalangan anak-anak usia sekolah dasar masih belum baik. ${ }^{12}$ Berdasarkan hal-hal tersebut di atas timbul satu permasalahan yang teridentifikasi yaitu apakah ada korelasi antara prevalensi gizi buruk dengan indikator BMI dengan status kesehatan gigi mulut anak usia sekolah dasar dengan salah satu parameternya yaitu def-t. Penelitian ini bertujuan mengetahui korelasi BMI dengan def-t dengan mengukur indeks masa tubuh dan indeks karies pada anak usia sekolah dasar di Kabupaten Bandung.

\section{METODE PENELITIAN}

Penelitian ini merupakan penilitian deskriptif dengan menggunakan metode cross sectional yang dilaksanakan di 5 sekolah dasar di sekitar Kabupaten Bandung yang ditentukan secara random. Jumlah sampel adalah 228 siswa sekolah dasar berusia 5-9 tahun dengan kriteria inklusi tidak memiliki sejarah penyakit sistemik dan telah mengisi informed consent yang diwakili oleh guru, sedangkan variable penelitian terdiri dari BMI dan def-t. Pengukuran BMI dilakukan secara antropometri dengan menimbang berat badan anak menggunakan timbangan digital setelah membuka sepatu dan atau jaket, sedangkan tinggi badan anak diukur dengan menggunakan pita pengukur yang dipasang pada dinding pada saat anak berdiri dengan punggung dan lutut lurus. Ukuran tinggi badan ditentukan hingga satu titik desimal terdekat.

Penghitungan indeks karies (def-t) didapat dengan cara memeriksa gigi sulung yang mengalami karies (d), eksfoliasi (e), dan penambalan (f), dan def-t merupakan hasil penjumlahan skala-skala tersebut. Def-t ditentukan berdasarkan karakterisasi WHO, yaitu: 0,0-1,1 adalah skor terendah, 1,2-2,6 adalah skor rendah, 2,7-4,4 adalah skor sedang, 4,5-6,5 adalah skor tinggi, dan 6,6 adalah skor tertinggi. Pengukuran BMI dilakukan oleh seorang operator (dokter umum), sedangkan pemeriksaan def-t delakukan oleh 5 orang dokter gigi yang sebelumnya telah dikalibrasi. Penelitian ini disetujui oleh Komite Etik Ilmiah (No: 979 / UN6.C.10 / PN / 2017), Fakultas Kedokteran, Universitas Padjadjaran di Bandung, Indonesia. Semua subjek penelitian diminta untuk menandatangani informed consent melalui orang tua atau guru untuk memenuhi aspek etika dan hukum penelitian.

\section{HASIL PENELITIAN}

Analisis deskriptif digunakan untuk memperoleh gambaran karakteristik sampel penelitian dan gambaran umum variabel penelitian. Karakteristik sampel terdiri dari jenis kelamin dan usia. Sedangkan variabel penelitian adalah BMI dan def-t. 
Tabel 1. Karakteristik Anak

\begin{tabular}{ccc}
\hline Karakteristik & Jumlah & Persentase (\%) \\
\hline Gender & & \\
Laki-laki & 132 & $57,9 \%$ \\
Perempuan & 96 & $42,1 \%$ \\
\hline Usia & & \\
5-7 Tahun & 201 & $88,2 \%$ \\
8-9 Tahun & 27 & $11,8 \%$ \\
\hline Total & 228 & $100,0 \%$ \\
\hline
\end{tabular}

Total seluruh anak yang masuk dalam kriteria adalah 228 orang dengan proporsi 57,9\% adalah lakilaki dan $42,1 \%$ perempuan. Anak yang berusia 5-7 tahun sebanyak 201 anak $(88,2 \%)$ dan sisanya berusia antara 8-9 tahun.

Tabel 2. Body Mass Index (BMI)

\begin{tabular}{cc}
\hline Kategori BMI & Jumlah \\
\hline Kurus Sekali & 11 \\
Kurus & 25 \\
Normal & 173 \\
Gemuk & 15 \\
Obesitas & 4 \\
\hline Total & 228 \\
\hline
\end{tabular}

Kategori indeks massa tubuh (BMI) terdiri dari kurus sekali, kurus, normal, gemuk dan obesitas (modifikasi Mojarad dan Liang). ${ }^{12,13}$ Berdasarkan hasil perhitungan, dapat dilihat bahwa komposisi anak yang memiliki BMI normal adalah 173 anak dari total 228 anak. 11 anak termasuk kurus, 25 anak termasuk kurus, 15 anak termasuk gemuk dan 4 anak termasuk dalam kriteria obesitas.

Tabel 3. Indeks def- $t$

\begin{tabular}{cccc}
\hline Def-t & Maksila & Mandibula & $\begin{array}{c}\text { Maksila+ } \\
\text { Mandibula }\end{array}$ \\
\hline Jumlah D & 902 & 694 & 1596 \\
Jumlah E & 216 & 190 & 406 \\
Jumlah F & 0 & 14 & 14 \\
Total & 1118 & 898 & 2016 \\
\hline Indeks def-t & $\mathbf{8 , 8 4}$ & & \\
\hline Kategori & Sangat Tinggi & \\
\hline
\end{tabular}

Total def-t maksila dan mandibula adalah 2016 yang apabila dibagi dengan jumlah anak (228) maka hasil indeksnya adalah 8,84 dengan kategori sangat tinggi. Berdasarkan data tersebut diperoleh informasi bahwa yang berjumlah paling banyak adalah decay dan eksfoliasi baik pada maksila maupun pada mandibula.

Tabel 4. BMI dan def-t Berdasarkan Gender

\begin{tabular}{lcc}
\hline \multirow{2}{*}{ Variabel } & \multicolumn{2}{c}{ Gender } \\
\cline { 2 - 3 } & Laki-laki (n=132) & Perempuan (n=96) \\
\hline BMI & & \\
$\bar{x} \pm S D$ & $14,47 \pm 1,96$ & $14,62 \pm 1,74$ \\
Min-Maks & $5,48-22,30$ & $11,16-19,92$ \\
\hline Def-t & & \\
$\bar{x} \pm S D$ & $8,96 \pm 3,99$ & $8,68 \pm 4,15$ \\
Min-Maks & $0,00-20,00$ & $0,00-18,00$ \\
\hline
\end{tabular}

Jika dilihat berdasarkan gender maka BMI dan def-t pada anak laki-laki dan perempuan tidak memiliki perbedaan yang cukup jauh. Def-t anak lakilaki memiliki rata-rata yang lebih tinggi dibandingkan anak perempuan.

Hasil uji korelasi untuk menghitung apakah terdapat korelasi antara BMI dan def-t dengan menggunakan korelasi Spearman rank disajikan pada tabel 6 dan 7.

Tabel 5. Korelasi BMI dengan def-t

\begin{tabular}{ccc}
\hline Variabel & Korelasi & p-value \\
\hline BMI $<-->$ def-t & $-0,062$ & $\mathbf{0 , 3 5 0}$ \\
\hline
\end{tabular}

Sumber: Output SPSS v23.0

Berdasarkan hasil perhitungan korelasi menggunakan Spearman rank terlihat adanya korelasi negative dengan nilai p korelasi berada di atas 0,05 . Artinya, tidak terdapat hubungan yang signifikan antara def-t dengan BMI.

Tabel 6. Korelasi BMI dengan def-t Berdasarkan Gender

\begin{tabular}{lcc}
\hline \multicolumn{1}{c}{ Variabel } & Korelasi & p-value \\
\hline Laki-laki & & \\
BMI $<-->$ Def-t & $-0,076$ & 0,385 \\
\hline Perempuan & & \\
BMI $<-->$ Def-t & $-0,035$ & 0,738 \\
\hline
\end{tabular}

Sumber: Output SPSS v23.0

Berdasarkan hasil perhitungan korelasi menggunakan Spearman rank terlihat adanya korelasi 
negative dengan nilai $\mathrm{p}$ korelasi berada di atas 0,05 baik pada anak laki-laki maupun perempuan. Hal ini menunjukkan bahwa tidak terdapat hubungan yang signifikan antara BMI dengan def-t baik pada anak laki-laki maupun pada anak perempuan.

\section{PEMBAHASAN}

Status kesehatan umum dengan salah satu parameternya adalah BMI memiliki pengaruh yang cukup besar terhadap kesehatan mulut demikian pula kesehatan mulut dapat mempengaruhi kesehatan umum. BMI adalah cara paling umum untuk menilai anak dengan kekurangan berat badan, berat badan normal atau kelebihan berat badan. Beberapa penyakit yang diderita oleh anak seperti infeksi, penyakit kronis dan penyakit genetik yang mempengaruhi BMI juga dapat mempengaruhi status kesehatan mulutnya. Peranan BMI dalam perkembangan kesehatan anak telah banyak disampaikan para peneliti yang menunjukkan adanya hubungan yang sangat erat diantara kedua hal tersebut. Sebagai contoh, anak penderita obesitas sering mengalami gangguan kesehatan umum serta kesehatan mulut. ${ }^{15}$, ${ }^{16}$ Hasil penelitian ini cukup kontradiktif terhadap hasil penelitian terdahulu dengan variabel yang sama yang dilakukan oleh Willerhausen dkk (2004). Penelitian Willerhausen menyatakan adanya hubungan antara BMI dan indeks DFT/dft yang memperlihatkan bahwa anak dengan berat normal memiliki dft 2,09, sedangkan anak yang memiliki berat badan berlebih dft-nya adalah 2,48, dan anak yang menderita obesitas dft-nya 3,3. Penelitian ini menyimpulkan adanya hubungan antara peningkatan karies gigi dan berat badan serta tinggi pada anak sekolah dasar. ${ }^{17}$

Meskipun demikian, penelitian yang dilakukan oleh Quadri dkk (2017) yang memeriksa BMI dan dft/ DMFT pada anak usia sekolah di kota Jazan, Saudi Arabia memperlihatkan indeks dft anak perempuan adalah 2,52 sementara anak laki-laki mempunyai indeks dft lebih rendah yaitu 1,88 dengan persentase anak yang mempunyai BMI normal sebanyak $60 \%$ dan persentase anak yang menderita obesitas adalah 4,7\%. Penelitian tersebut juga memperlihatkan hasil bahwa $81 \%$ anak yang memiliki karies gigi yang tidak dirawat cenderung memiliki BMI rendah, tetapi secara statistik tidak terbukti adanya relasi positif antara BMI dan dft. ${ }^{18}$ Hasil penelitian Quadri sejalan dengan hasil penelitian ini. Penelitian lain yang memperlihatkan hasil yang sama dengan penelitian ini adalah penelitian Sadeghi dan Alizadeh (2007) yang dilakukan pada anak-anak dengan berat badan normal, berat badan berlebih, dan obesitas. Penelitian Sadeghi dan Alizadeh memperlihatkan adanya perbedaan dft pada kelompok anak-anak tersebut tetapi secara statistik tidak memperlihatkan adanya hubungan yang signifikan antara BMI dan dft. ${ }^{19}$ Mojarad dan Maybodi (2009) juga telah melakukan penelitian tentang hubungan BMI dan karies gigi pada 1000 orang anak sekolah dasar di Iran, dan hasilnya menunjukkan bahwa tidak ada hubungan antara BMI dan karies gigi. ${ }^{12}$ Dengan demikian, dapat disimpulkan bahwa hasil penelitian ini relevan dengan beberapa hasil penelitian terdahulu yang memperlihatkan tidak adanya hubungan yang signifikan antara BMI dengan karies gigi terutama di kalangan anak-anak usia sekolah dasar.

Penelitian tentang hubungan BMI dengan indeks karies DMFT maupun def-t sudah sangat banyak dilakukan di berbagai negara dengan hasil yang berbeda-beda dan cukup kontraindiktif. Berdasarkan hasil review, beberapa peneliti menyatakan bahwa hubungan antara BMI dan karies gigi merupakan hubungan yang sangat kompleks yang secara statistik pada umumnya dinyatakan tidak ada perbedaan signifikan pada karies yang ditemukan antara kelompok dengan berat badan abnormal dan kelompok dengan berat badan normal untuk gigi sulung dan permanen..$^{20,21}$ Tetapi, penelitian yang dilakukan di beberapa negara berpenghasilan tinggi menunjukkan bahwa anak-anak yang mengalami obesitas memiliki lebih banyak karies baik pada gigi sulung maupun gigi permanennya dibandingkan kelompok anak dengan berat normal. Hal ini terjadi karena tingginya konsumsi karbohidrat yang dapat difermentasi seperti gula yang merupakan faktor utama penyebab karies gigi dan penambahan berat badan. Secara biologis, obesitas dapat mengakibatkan berkurangnya aliran saliva yang mana hal ini juga merupakan faktor penyebab karies gigi. ${ }^{21}$ Karies gigi merupakan kelainan multifaktorial yang memiliki keterkaitan sangat erat dengan faktor risiko lainnya seperti jenis kelamin, ras/etnis, status sosial, dan gizi. Faktor utama yang mempengaruhi timbulnya karies gigi adalah kebersihan mulut, komposisi makanan dan frekuensi konsumsinya, immunoglobulin saliva, bakteri, dan asupan atau penggunaan fluor ditambah status sosial ekonomi sebagai faktor pendukung. Faktor-faktor tersebut diduga menjadi faktor pengganggu bagi penelitian karena beberapa peneliti tidak mempertimbangkan faktor-faktor tersebut sebagai kriteria inklusi atau eksklusi di dalam penelitiannya sehingga hasilnya sangat beragam. ${ }^{13,22}$

Sebagian besar subjek penelitian ini memiliki berat badan normal tetapi rata-rata def-t subjek penelitian sangat tinggi yaitu 8,84 . Hal ini disebabkan kesadaran akan kesehatan gigi mulut di kalangan subjek penelitian masih rendah, keterampilan menyikat gigi belum baik, pengaruh sosial dan ekonomi, serta kebiasan mengonsumsi jajanan di sekitar sekolah yang dapat menyebabkan karies gigi. Jika mengacu kepada hasil penelitian terdahulu, anak usia sekolah dasar yang memiliki berat badan normal memperlihatkan def-t lebih rendah dibandingkan dengan anak-anak yang memiliki berat badan di bawah normal, tetapi hal ini bukan berarti BMI 
yang rendah merupakan penyebab tingginya def-t karena bisa jadi tingginya def-t diakibatkan oleh karies yang tidak dirawat sehingga menyebabkan rasa sakit dan ketidaknyamanan yang parah pada anak dengan demikian asupan makanan menjadi berkurang. ${ }^{23}$ Tingginya def-t pada subjek penelitian ini kemungkinan disebabkan karena kurangnya pemahaman orang tua terhadap kesehatan gigi mulut meskipun fasilitas kesehatan gigi di Puskesmas sudah tersedia yang mudah dijangkau dan gigi mulut anakanak secara rutin diperiksa oleh petugas kesehatan gigi melalui program UKGS. Faktor penyebab lainnya adalah status sosial ekonomi, kebiasaan konsumsi makanan, dan perilaku. Meskipun hasil penelitian ini tidak menunjukkan adanya hubungan antara BMI dan def-t, faktor gizi anak harus tetap menjadi perhatian utama dalam upaya pencegahan penyakit umum dan gigi serta untuk meningkatkan kesehatan umum dan gigi anak di masa mendatang.

\section{KESIMPULAN DAN SARAN}

Def-t anak usia sekolah dasar di Kabupaten Bandung sangat tinggi, tetapi tidak terdapat hubungan antara BMI dan def-t baik pada anak laki-laki maupun perempuan usia sekolah dasar di Kabupaten Bandung. Penelitian lebih lanjut yang bersifat longitudinal perlu dilakukan untuk mengonfirmasi hasil penelitian ini dan untuk menentukan mekanisme hubungan BMI dan karies gigi dengan mempertimbangkan faktor-faktor yang mempunyai peranan penting di dalam proses terjadinya karies gigi.

\section{UCAPAN TERIMAKSIH}

Penulis mengucapkan terima kasih kepada Kementerian Riset, Teknologi, dan Pendidikan Tinggi Republik Indonesia yang telah mendanai penelitian ini melalui Universitas Padjadjaran, Bandung, dan kepada semua peneliti yang telah memberikan kontribusi dalam kegiatan penelitian ini.

\section{DAFTAR PUSTAKA}

1. Elfarisi RN, Susilawati S, Suwargiani AA. Kesehatan gigi dan mulut terkait kualitas hidup anak usia 4-5 tahun di Desa Cilayung. J Ked Gi Unpad. 2018; 30(2): 85-94

2. Andreeva A, Beltcheva. The importance of the OHI-S for children with premature tooth loss. R.Scripta Sci Med Dent J. 2016; 2(1): 50-3.

3. Anitasari S, Liliwati. Pengaruh frekuensi menyikat gigi terhadap tingkat kebersihan gigi dan mulut siswa-siswi Sekolah Dasar Negeri di Kecamatan Palaran Kotamadya Samarinda Propinsi Kalimantan Timur. Dentika Dent J. 2005; 10(1): 22-7.

4. Burt BA, Pai S. Sugar consumption and caries risk: a systematic review. J Dent Educ 2001; 65(10): 1017-23.

5. Damyanova DM, Panov VE, Angelova ST. Improvement of oral hygiene status in children influenced by motivation programs. J IMAB. 2015; 21(3): 879-82.
6. Damyanova D, Georgieva I, Ivanova K. Determination of oral hygiene status (OHI-S) of two groups of children and comparison with caries incidence of temporary teeth and age. AJER. 2017; 6(10): 130-5.

7. Rathod V, Thorat V, Shetty A, Avhad R. Relationship between body mass index and periodontal health status: an observational study. International Journal of Preventive and Clinical Dental Research. 2017; 4(1): 1- 4.

8. Halite F, Begzati A, Krasniqi S, Shabani N, Mehmeti B, Ibraimi $\mathrm{Z}$, et.al. Correlation between body mass index (BMI), dental caries and respiratory system disease among $8-15$ years old patients in Kosovo: A Pilot Study. Journal of International Dental and Medical Research. 1020; 17 (1): 24-29,

9. Begzati A, Meqa K, Xhemali-Latifi B, Kutllovci T, Berisha M. Oral health status, malocclusions, and S. mutants counts in children with Down's syndrome. J Int Dent Med Res. 2017; 10(3): 856-61.

10. Rachmawati E, Nindita DC, Susanto A, Mustika I, Primarti RS. Correlation between oral hygiene indexsimplified (OHI-S) and various body mass index (BMI) among 6-8 years old children in Bandung City. IJSR. 2016; 7(1): 490-93.

11. Manuhutu R, Purnamasari DU, Dardjito E. The effect of energy, protein, fat consumption rate and worm infectional status to the sdn 01 Limpakuwus student's nutritional status. JurnalKesmas Indonesia. 2017; 9(1): 46-55

12. Rachmawati E, Setiawan AS, Hayati AT, Saptarini RS, Nindita DC, Rusminah N. Determination of oral hygiene status (OHI-S) and dental health status (def-t) of elementary school age children in Bandung City. JIDMR. 2019; 12(4): 1447-51

13. Mojarad F, Maybodi MH. Association between dental caries and body mass index among hamedan elementary school children in 2009. Journal of Dentistry, Tehran University of Medical Sciences. 2011; 8(4): 170-77

14. Liang J, Zhang Z, Chen Y, Mai J, Ma J, Yang W, Jing $J$. Dental caries is negatively correlated with body mass index among 7-9 years old children in Guangzhou, China. BMC Public Health. 2016; 16(638): 2-7

15. T.J. Cole, T. Lobstein, "Extended International (IOTF) body mass index cut-offs for thinness, overweight and obesity, PediatrObes. 2012; 7: 284 - 294

16. N. Patel, G. Gunjana, S. Patel, R. Thanvi, P. Sathvara, R. Joshi, "Nutrition and health status of school children in urban area of Ahmedabad, India: Comparison with Indian Council of Medical Research and body mass index standards," J Nat SciBiol Med. 2015; 6(2): 372 - 377

17. Willershausen B, Hass G, Krummenauer F, Hohenfellner K. Relationship between high weight and caries frequency in German elementary school children. Eur J Med Res. 2004; 9: 400 - 404.

18. Quadri MF, Hakami BM, Hezam AA, Hakami RY, Saadi FA, Ageeli LM. Relation between Dental Caries and Body Mass Index-for-age among Schoolchildren of Jazan City, Kingdom of Saudi Arabia. J Contemp Dent Pract. 2017; 18(4): 277-82

19. Sadeghi M, Alizadeh F. Association between dental caries and body mass index-for-age among 6-11-yearold children in Isfahan in 2007. JODDD. 2007; 3(1): 119-24 
20. Chen D, Zhi Q, Zhou Y, Tao Y, Wu L, Lin H. Association between dental caries and BMI in children: a systematic review and meta-analysis. Caries Res. 2018; 52(3): 230-45.

21. Alshehri YFA, Park JS, Kruger E, Tennant M. Association between body mass index and dental caries in the Kingdom of Saudi Arabia: Systematic review. Saudi Dental Journal. 2020; 32: 171-80
22. Koksal E, Tekcicek M, Yalcin SS, Tugrul, B, Yalcin S, Pekcan G. Association between anthropometric measurements and dental caries in turkish school children. Cent Eur J Public Health. 2011; 19 (3):147-151

23. Norberg C, Stalin UH, Matsson L, Thorngren-Jerneck $\mathrm{K}$, Klingberg G. Body mass index (BMI) and dental caries in 5-year-old children from Southern Sweden. Community Dentistry And Oral Epidemiology. 2012; 40(4): $315-22$ 